\title{
Recycling of Expired Ceftamil Drug as Additive in the Copper and Nickel Electrodeposition from Acid Baths
}

\author{
Delia-Andrada Duca, Mircea Laurentiu Dan * and Nicolae Vaszilcsin
}

check for updates

Citation: Duca, D.-A.; Dan, M.L.; Vaszilcsin, N. Recycling of Expired Ceftamil Drug as Additive in the Copper and Nickel Electrodeposition from Acid Baths. Int. J. Environ. Res. Public Health 2021, 18, 9476. https:// doi.org/10.3390/ijerph18189476

Academic Editor: Paul B. Tchounwou

Received: 13 July 2021

Accepted: 5 September 2021

Published: 8 September 2021

Publisher's Note: MDPI stays neutral with regard to jurisdictional claims in published maps and institutional affiliations.

Copyright: (c) 2021 by the authors. Licensee MDPI, Basel, Switzerland. This article is an open access article distributed under the terms and conditions of the Creative Commons Attribution (CC BY) license (https:/ / creativecommons.org/licenses/by/ $4.0 /)$.
Faculty of Industrial Chemistry and Environmental Engineering, University Politehnica Timișoara, 300223 Timișoara, Romania; duca.delia@gmail.com (D.-A.D.); nicolae.vaszilcsin@upt.ro (N.V.)

* Correspondence: mircea.dan@upt.ro; Tel.: +40-720-093-002

\begin{abstract}
Due to the large quantity of expired and unused drugs worldwide, pharmaceutical disposal has become a serious problem that requires increased attention. In the present paper, the study on recycling ceftazidime $(\mathrm{CZ})$ as an additive in copper and nickel electrodeposition from acid baths is highlighted. $\mathrm{CZ}$ is the active substance from expired commercial drug Ceftamil ${ }^{\circledR}$. Its electrochemical behavior was studied by cyclic voltammetry. As well, kinetic parameters for copper and nickel electrodeposition were determined using Tafel plots method at different temperatures and CZ concentrations in these acid baths. The activation energy was calculated from Arrhenius plots. Electrochemical impedance spectroscopy was used to investigate the charge transfer resistance and coverage degree in the electrolyte solutions at several potential values. Gibbs free energy values, calculated from Langmuir adsorption isotherms, revealed the chemical nature of CZ-electrode surface interactions. The favorable effect of the organic molecules added in copper and nickel electroplating baths was emphasized by optical microscope images. The morphology of the obtained deposits without and with $10^{-4}$ mol L ${ }^{-1} \mathrm{CZ}$ was compared. The experimental results revealed that expired Ceftamil $^{\circledR}$ is suitable as additive in copper and nickel electroplating processes from acid baths.
\end{abstract}

Keywords: expired drug; drug recycling; electroplating additive; levelling agent; galvanotechnics; Tafel method; electrochemical impedance spectroscopy

\section{Introduction}

Every year, a great amount of pharmaceutical products expires around the world, making them unusable for the treatment of patients or other medical purposes [1-9]. Most of them are incinerated in order to avoid environment contamination [10-13], but some of them, as in the household area, are difficult to track and commonly end up in the residual water due to improper disposal techniques [14-17]. Unfortunately, a large number of unused drugs have become hazardous contaminants in soil, surface and ground water, endangering ecosystem and human health [18,19].

Certain products from a large number of drugs contain only active substances, without excipients. These are usually organic molecules with a complex chemical structure and large molecular area, which can find other utilities in various electrochemical processes, like levelling or brightening agents in galvanotechnics [20-22], anodes for lithium-ion batteries [23], as well as corrosion inhibitors for metals in different aggressive media [24-26].

In terms of environmental impact, the possibility to reuse expired drugs as additives in galvanic baths is the most advantageous, because only a very small fraction of them is embedded in the final cathodic deposit. Electroplating bath composition remains constant for a long time, requiring corrections only at appreciable intervals [27-29]. Additives are very important due to their influence on physical and mechanical properties of the deposited metallic layer. Generally, they act by adsorption onto the metal surface, inhibiting the electrodeposition process, thus reducing the grain size of the metallic deposit [30-32].

$\mathrm{CZ}$ is an antibiotic from third generation cephalosporins group with a large activity spectrum, but enhanced activity against Pseudomonas spp. The IUPAC name of CZ 
is: (Z)-(7R)-7-[2-(2-Aminothiazol-4-yl)-2-(1-carboxy-1-methylethoxyimino)acetamido]-3-(1pyridiniomethyl)-3-cephem-4-carboxylate pentahydrate. Its chemical structure is presented in Figure 1.<smiles>CC(C)(O/N=C(/CN[C@@H]1CN2C(C(=O)O)C(C[n+]3ccccc3)CS[C@H]12)c1csc(N)n1)C(=O)O</smiles>

Figure 1. CZ chemical structure.

CZ contains several structures, such as double bounds, aromatic rings, and heteroatoms with lone pair electrons which confer its inhibitive properties in the electrode processes [33].

In this paper, the possibility to use $C Z$ active substance from expired Ceftamil ${ }^{\circledR}$ drug as additive in copper and nickel electroplating is studied. A similar galvanic baths composition was used by Badarulzaman et al. [34] and Pasquale et al. [35] for nickel and copper electrodeposition, respectively.

\section{Materials and Methods}

Electrochemical measurements were performed using a PARSTAT 2273 potentiostat/galvanostat in a $150 \mathrm{~mL}$ thermostatted glass cell. $\mathrm{Pt}, \mathrm{Cu}$, and Ni electrodes, having $0.5 \mathrm{~cm}^{2}$ exposed area, were used as working electrodes, two graphite rods as counter electrodes and saturated $\mathrm{Ag} / \mathrm{AgCl}$ as reference. All further potentials from the experimental work are referred to this electrode $\left(E_{\mathrm{Ag} / \mathrm{AgCl}}=+0.197 \mathrm{~V}\right.$ vs. normal hydrogen electrode).

$\mathrm{CZ}$ electrochemical behavior has been studied by cyclic voltammetry. Cyclic voltammograms (CVs) have been recorded on Pt electrode in $0.5 \mathrm{~mol} \mathrm{~L}^{-1} \mathrm{H}_{2} \mathrm{SO}_{4}$ as well in $0.5 \mathrm{~mol} \mathrm{~L}^{-1} \mathrm{Na}_{2} \mathrm{SO}_{4}+30 \mathrm{~g} \mathrm{~L}^{-1} \mathrm{H}_{3} \mathrm{BO}_{3}$ electrolyte solution (BS) in the absence and presence of different $\mathrm{CZ}$ concentrations, with scan rates between 5 and $500 \mathrm{mV} \mathrm{s}^{-1}$, at $25^{\circ} \mathrm{C}$ temperature.

Kinetic parameters for copper and nickel electrodeposition have been calculated from Tafel plots. Linear voltammograms (LVs) have been drawn with low scan rate $\left(2 \mathrm{mV} \mathrm{s}^{-1}\right)$ in 25-65 ${ }^{\circ} \mathrm{C}$ temperature range on copper electrode in $5 \mathrm{~g} \mathrm{~L}^{-1} \mathrm{Cu}^{2+}$ solution $\left(0.5 \mathrm{~mol} \mathrm{~L}^{-1}\right.$ $\mathrm{H}_{2} \mathrm{SO}_{4}+5 \mathrm{~g} \mathrm{~L}^{-1} \mathrm{Cu}^{2+}$ from $\mathrm{CuSO}_{4} \cdot 5 \mathrm{H}_{2} \mathrm{O}$ ) and on nickel electrode in $5 \mathrm{~g} \mathrm{~L}^{-1} \mathrm{Ni}^{2+}$ solution ( $30 \mathrm{~g} \mathrm{~L}^{-1} \mathrm{H}_{3} \mathrm{BO}_{3}+5 \mathrm{~g} \mathrm{~L}^{-1} \mathrm{Ni}^{2+}$ from $20.32 \mathrm{~g} \mathrm{~L}^{-1} \mathrm{NiSO}_{4} \cdot 7 \mathrm{H}_{2} \mathrm{O}$ and $3.05 \mathrm{~g} \mathrm{~L}^{-1} \mathrm{NiCl}_{2} \cdot 6 \mathrm{H}_{2} \mathrm{O}$ ) in the absence and presence of different concentrations of $\mathrm{CZ}$. For both processes, the activation energy has been calculated from Arrhenius plots.

Based on the dependence between the $\mathrm{CZ}$ concentration added in the electrolyte solutions and surface coverage degree, using Langmuir adsorption isotherms, drawn at different deposition potentials, Gibbs free energy values were calculated. From its values, the nature of interaction between $\mathrm{CZ}$ and the metal substrate can be appreciated.

Electrochemical impedance spectroscopy (EIS) studies were recorded on a BioLogic SP150 potentiostat/galvanostat equipped with an EIS module, in the frequency range between $10 \mathrm{mHz}$ and $100 \mathrm{kHz}$, the amplitude of the alternating voltage was $10 \mathrm{mV}$. For each measurement 60 points with a logarithmic distribution of 10 points per decade were 
recorded. The experimental data were fitted using the ZView-Scribner Associates Inc. software and equivalent electrical circuits by applying the Levenberg-Marquardt least squares complex non-linear fitting algorithm. The EIS results are given in Supplementary Materials (Figures S3-S5, Tables S1 and S2).

Further, copper discs were used as substrate for copper and nickel electrodeposition. Copper was plated in a bath containing $0.5 \mathrm{~mol} \mathrm{~L}^{-1} \mathrm{H}_{2} \mathrm{SO}_{4}$ and $250 \mathrm{~g} \mathrm{~L}^{-1} \mathrm{CuSO}_{4} \cdot 5 \mathrm{H}_{2} \mathrm{O}$, while for nickel a Watts bath $\left(300 \mathrm{~g} \mathrm{~L}^{-1} \mathrm{NiSO}_{4} \cdot 7 \mathrm{H}_{2} \mathrm{O}, 45 \mathrm{~g} \mathrm{~L}^{-1} \mathrm{NiCl}_{2} \cdot 6 \mathrm{H}_{2} \mathrm{O}\right.$ and $30 \mathrm{~g} \mathrm{~L}^{-1}$ $\mathrm{H}_{3} \mathrm{BO}_{3}$ ) was used. Both depositions were performed at $25^{\circ} \mathrm{C}$ from baths without and with $10^{-4} \mathrm{~mol} \mathrm{~L}^{-1} \mathrm{CZ}$. The morphology and roughness of the surfaces was evaluated using a laser microscope (Lext OLS 4000, 3D measuring laser microscope, Olympus). The results from the analysis gained by using the roughness measurement module from the microscope software were compared. The measured values were calculated on surfaces collected on micrographs taken at $100 \times$ magnification.

All test solutions were prepared from high purity reagents: $\mathrm{H}_{2} \mathrm{SO}_{4}$ Merck p.a. 95 $97 \%, \mathrm{Na}_{2} \mathrm{SO}_{4}$ anhydrous Sigma-Aldrich p.a. $\geq 99 \%, \mathrm{H}_{3} \mathrm{BO}_{3}$ Sigma-Aldrich p.a. $\geq 99.5 \%$, $\mathrm{CuSO}_{4} \cdot 5 \mathrm{H}_{2} \mathrm{O}$ Merck p.a. $\geq 98 \%, \mathrm{NiSO}_{4} \cdot 7 \mathrm{H}_{2} \mathrm{O}$ Sigma-Aldrich p.a. $\geq 99 \%, \mathrm{NiCl}_{2} \cdot 6 \mathrm{H}_{2} \mathrm{O}$ Merck p.a. $\geq 97 \%$. In the experimental studies, different concentrations of $\mathrm{CZ}$, between $10^{-6}$ and $10^{-3} \mathrm{~mol} \mathrm{~L}^{-1}$, from expired Ceftamil ${ }^{\circledR}$ commercial drug (expiration date: January 2013) were used as additive in the electrolyte solutions. A vial of Ceftamil ${ }^{\circledR}$ contains $1.16 \mathrm{~g}$ pentahydrate form of $\mathrm{CZ}$ along with $0.2 \mathrm{~g}$ sodium carbonate as powder for injection solution.

\section{Results and Discussion}

\subsection{Electrochemical Behavior of CZ}

Studies on the possibility to use $\mathrm{CZ}$ as additive (levelling agent) in copper and nickel electrodeposition started with its electrochemical behavior, characterized by cyclic voltammetry recorded on platinum electrode in $0.5 \mathrm{~mol} \mathrm{~L}^{-1} \mathrm{H}_{2} \mathrm{SO}_{4}$ and $\mathrm{BS}$, in a wide potential range. Concerning the nature of acids and their concentrations, as well as the $\mathrm{pH}$, both of the electrolyte solutions used are similar with those used at industrial level in galvanotechnics: $0.5 \mathrm{~mol} \mathrm{~L}^{-1} \mathrm{H}_{2} \mathrm{SO}_{4}$ for copper electrodeposition from acid baths $(\mathrm{pH}=0-1$ ), respectively $30 \mathrm{~g} \mathrm{~L}^{-1} \mathrm{H}_{3} \mathrm{BO}_{3}$ for nickel electrodeposition from Watts baths $(\mathrm{pH}=3.5-4.5)$.

Figure 2 illustrates the $\mathrm{CVs}$ drawn on platinum electrode with $500 \mathrm{mV} \mathrm{s}^{-1}$ scan rate in $0.5 \mathrm{~mol} \mathrm{~L}^{-1} \mathrm{H}_{2} \mathrm{SO}_{4}$ (Figure 2a) and BS (Figure 2b).

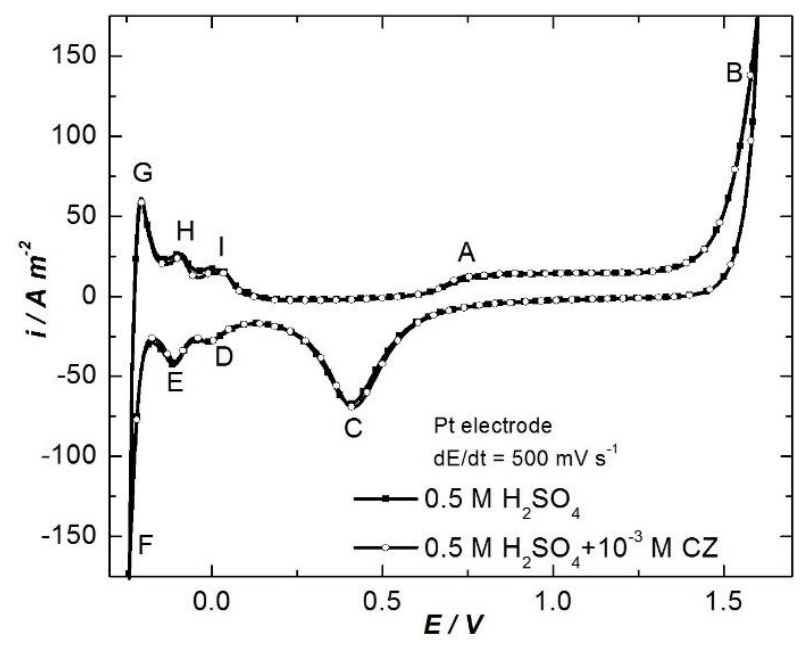

(a)

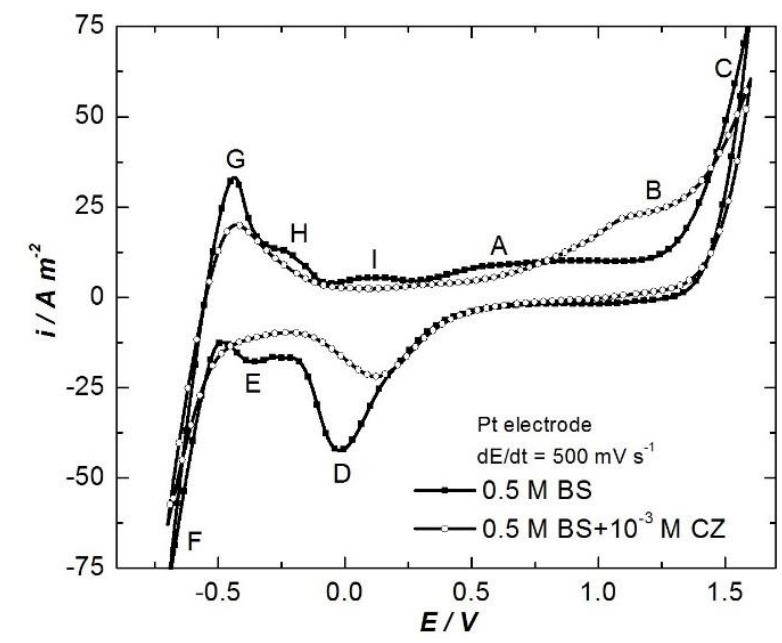

(b)

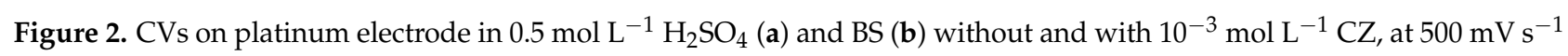
scan rate. 
Analyzing the curves from Figure 2a, it is observed that in strong acid media $\left(\mathrm{H}_{2} \mathrm{SO}_{4}\right)$, $\mathrm{CZ}$ does not undergo electrochemical reactions at either the anode or cathode. At high scan rate, peaks and waves assigned to the superficial oxidation of platinum substrate $\mathrm{A}$ $($ about $+0.75 \mathrm{~V}$ ) and oxygen evolution B (about $+1.50 \mathrm{~V})$ can be distinguished (at anodic polarization), as well as its reduction peak $\mathrm{C}$ (approx. $+0.40 \mathrm{~V}$ ), followed by the generation of adsorbed hydrogen atoms $\left(\mathrm{H}_{\mathrm{ads}}\right) \mathrm{D}$ (about $\left.0 \mathrm{~V}\right)$, adsorbed hydrogen molecules $\left(\mathrm{H}_{2 \mathrm{ads}}\right) \mathrm{E}$ (approx. $-0.15 \mathrm{~V}$ ), and $\mathrm{H}_{2}$ evolution $\mathrm{F}$ (about $-0.25 \mathrm{~V}$ ), and their oxidation correspondents $(\mathrm{G}, \mathrm{H}, \mathrm{I})$, when the potential is shifted towards positive values.

However, in weak acid media $\left(\mathrm{H}_{3} \mathrm{BO}_{3}\right)$, the electrochemical behavior of $\mathrm{CZ}$ is different than in strong acid solution, most probably due to the change of the protonation degree of the active substance of the drug. On the curve drawn in BS (Figure 2b), an oxidation plateau (B) is observed around $+0.75-+1.25 \mathrm{~V}$, associated with $\mathrm{CZ}$ oxidation to various products.

At low scan rate $\left(5 \mathrm{mV} \mathrm{s}^{-1}\right.$ ) (Figure 3) on the $\mathrm{CVs}$ recorded in $\mathrm{H}_{2} \mathrm{SO}_{4}$, only $\mathrm{O}_{2}$ evolution, $\mathrm{O}_{2 \text { ads }}$ reduction, $\mathrm{H}_{2}$ evolution and $\mathrm{H}_{2 \text { ads }}$ oxidation peaks and waves can be observed. In BS, in addition to these, the $\mathrm{CZ}$ oxidation wave can be seen.

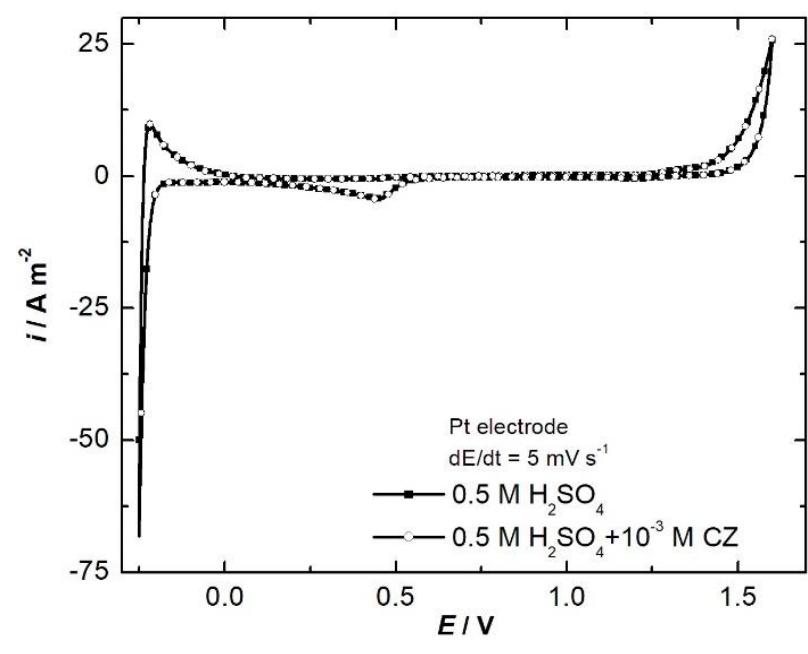

(a)

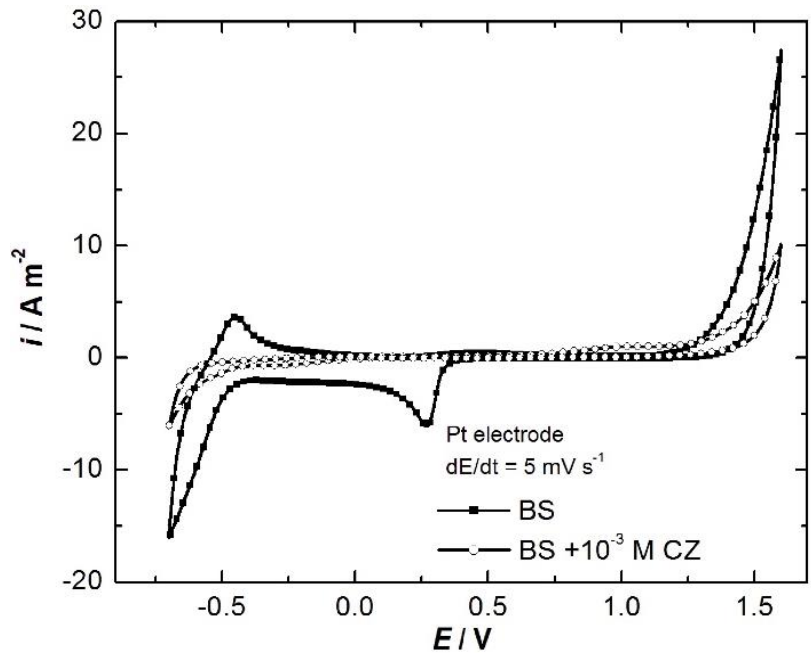

(b)

Figure 3. CVs (cycle 3) on platinum electrode $0.5 \mathrm{~mol} \mathrm{~L}^{-1} \mathrm{H}_{2} \mathrm{SO}_{4}(\mathbf{a})$ and $0.5 \mathrm{~mol} \mathrm{~L}^{-1} \mathrm{Na}_{2} \mathrm{SO}_{4}+30 \mathrm{~g} \mathrm{~L}^{-1} \mathrm{H}_{3} \mathrm{BO} 3(\mathrm{BS})(\mathbf{b})$ without and with $10^{-3} \mathrm{~mol} \mathrm{~L}^{-1} \mathrm{CZ}$, at $5 \mathrm{mV} \mathrm{s}^{-1}$ scan rate.

Each wave's intensity of oxygen and hydrogen evolution reaction diminishes, simultaneously with the increase of the overpotentials, due to the inhibitory effect of $\mathrm{CZ}$ and its oxidation products, which are adsorbed onto the electrode surface.

Based on the above presented CVs, it can be stated that in copper acid baths, CZ will not undergo any transformation at the electrodes; consequently, its concentration will remain almost constant during copper electroplating for long periods. In addition, $\mathrm{CZ}$ will not degrade, even in BS, since during anodic ionization of nickel the polarization is not pronounced enough to oxidize the organic compound.

\subsection{Inhibitory Effect of $C Z$ on Copper and Nickel Electrodeposition}

In order to determine the kinetic parameters of copper and nickel electrodeposition, LVs have been recorded with low scan rate $\left(2 \mathrm{mV} \mathrm{s}^{-1}\right)$ on copper and nickel electrodes in solutions containing $5 \mathrm{~g} \mathrm{~L}^{-1}$ metal ions in $0.5 \mathrm{~mol} \mathrm{~L}^{-1} \mathrm{H}_{2} \mathrm{SO}_{4}$ for copper bath and in $30 \mathrm{~g} \mathrm{~L}^{-1} \mathrm{H}_{3} \mathrm{BO}_{3}$ for nickel bath. Both the influence of $\mathrm{CZ}$ added in the electrolyte solution and the temperature effect on these processes have been studied.

LVs (Figures 4 and 5) and correspondent Tafel plots [36] (Figures S1 and S2 presented in Supplementary Materials) have been drawn for $\mathrm{Cu}$ and for Ni electrode respectively in 
electrolyte solutions without and with different concentrations of $C Z$ (between $10^{-6}$ and $10^{-3} \mathrm{~mol} \mathrm{~L}^{-1}$ ).

Knowing the beneficial effect of temperature on the electrodeposition mechanisms of both metals, as well as on the quality of the obtained metallic deposits, LVs were recorded in $25-55{ }^{\circ} \mathrm{C}$ temperature range for copper and $25-65^{\circ} \mathrm{C}$ for nickel electrodeposition. Figure $4 \mathrm{~b}$ presents the LVs plotted in $5 \mathrm{~g} \mathrm{~L}^{-1} \mathrm{Cu}^{2+}$ and Figure $5 \mathrm{~b}$ the ones in $5 \mathrm{~g} \mathrm{~L}^{-1} \mathrm{Ni}^{2+}$, both of them with addition of $10^{-3} \mathrm{~mol} \mathrm{~L}^{-1} \mathrm{CZ}$ as additive.

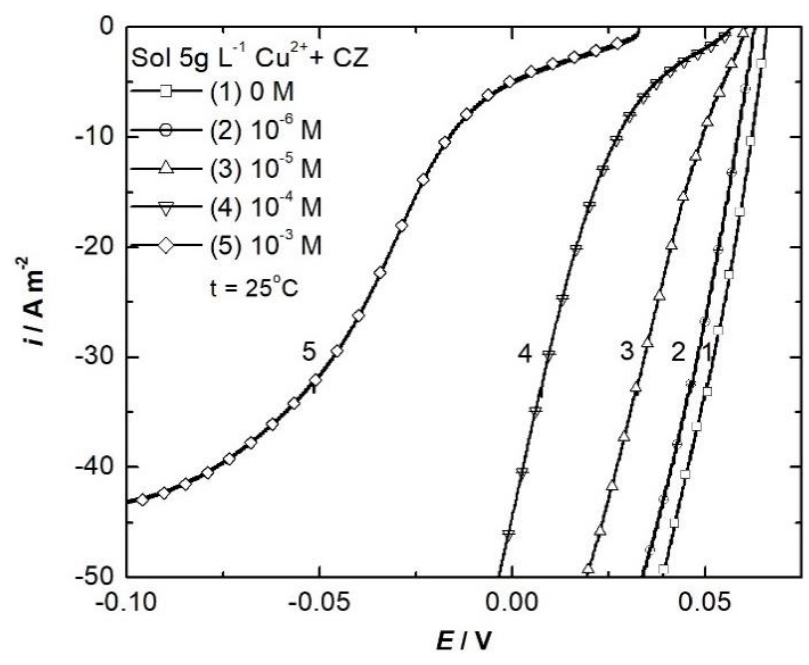

(a)

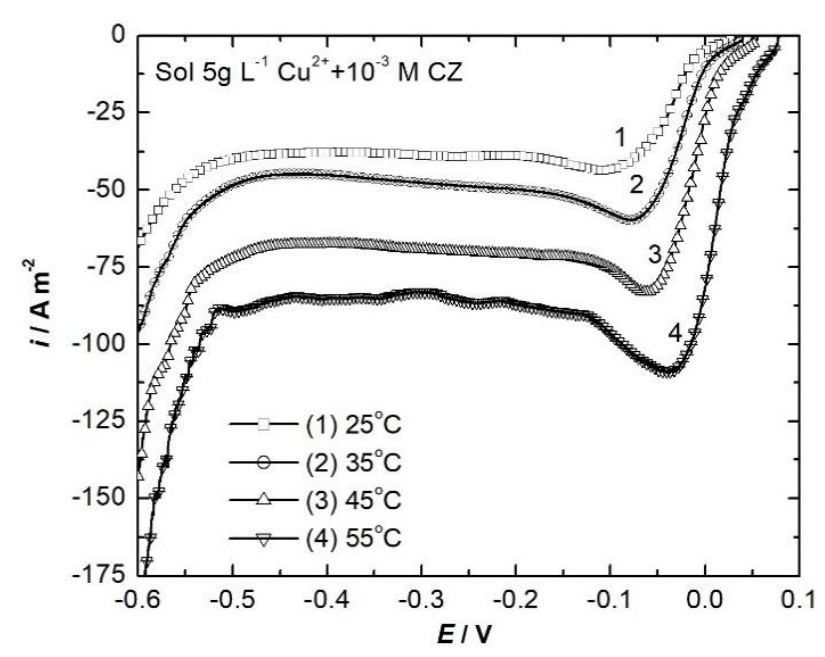

(b)

Figure 4. LVs recorded for copper electrodeposition without and with different concentrations of $\mathrm{CZ}$ at $25^{\circ} \mathrm{C}$ (a) and with $10^{-3} \mathrm{~mol} \mathrm{~L}^{-1} \mathrm{CZ}$ at different temperatures (b), $2 \mathrm{mV} \mathrm{s}^{-1}$ scan rate.

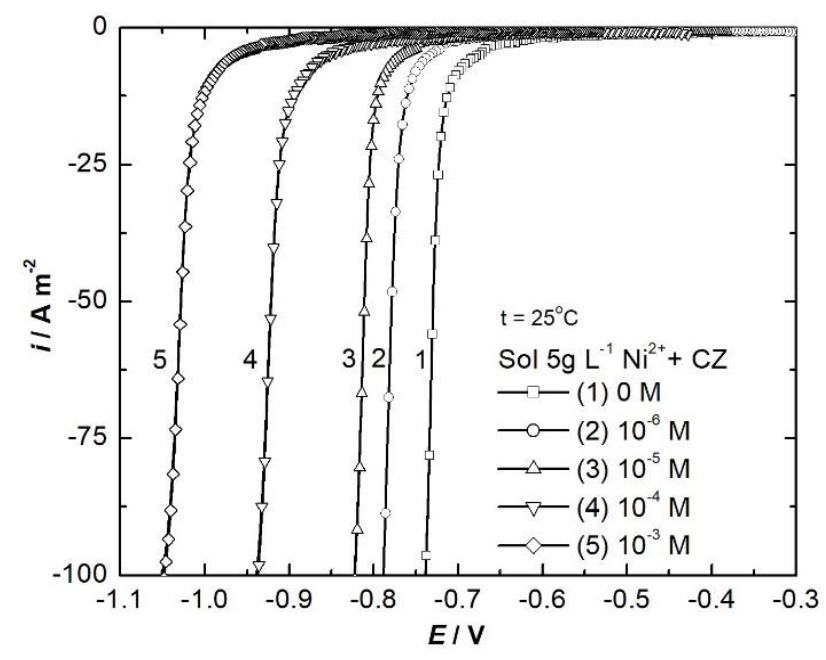

(a)

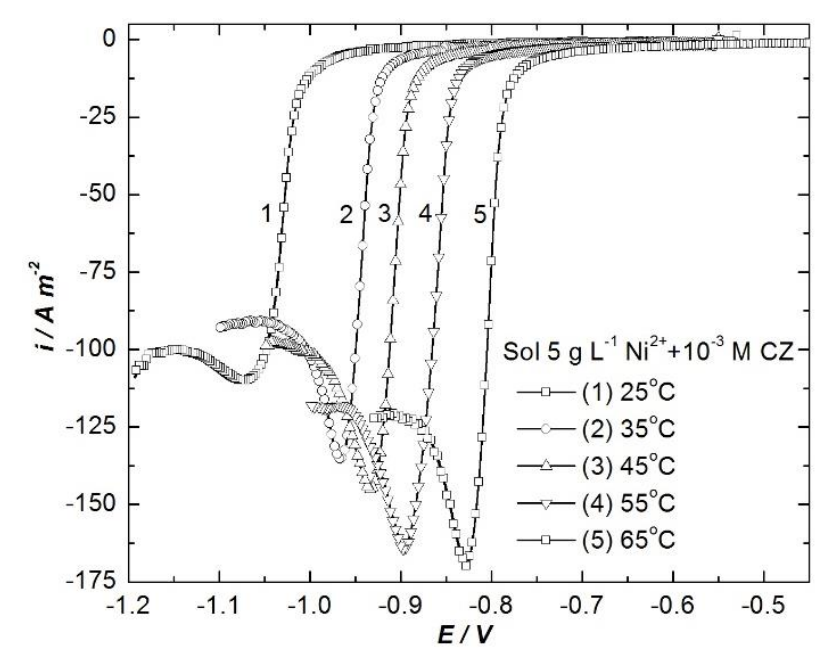

(b)

Figure 5. LVs recorded for nickel electrodeposition without and with different concentrations of $\mathrm{CZ}$ at $25^{\circ} \mathrm{C}$ (a) and with $10^{-3} \mathrm{~mol} \mathrm{~L}^{-1} \mathrm{CZ}$ at different temperatures (b), $2 \mathrm{mV} \mathrm{s}^{-1}$ scan rate.

The LVs show that there are not additional peaks and waves in the presence of $C Z$, indicating the organic molecules are not implicated in any reduction processes; they are stable and the only phenomenon occurring at the interface is their adsorption onto the metal surface, thus inhibiting the metal deposition. This is also supported by the negative shift of about $100 \mathrm{mV}$ for copper electrodeposition potential and $300 \mathrm{mV}$ for nickel.

The kinetic parameters for copper electrodeposition are shown in Table 1 and for nickel electrodeposition in Table 2. 
Table 1. Kinetic parameters for copper deposition from $5 \mathrm{~g} \mathrm{~L}^{-1} \mathrm{Cu}^{2+}$ without and with different concentrations of $\mathrm{CZ}$, in $25-55^{\circ} \mathrm{C}$ temperature range.

\begin{tabular}{|c|c|c|c|}
\hline CZ Conc. $\left(\mathrm{mol} \mathrm{L}^{-1}\right)$ & $t\left({ }^{\circ} \mathrm{C}\right)$ & $1-\alpha$ & $i_{o}\left(\mathrm{~A} \mathrm{~m}^{-2}\right)$ \\
\hline \multirow{4}{*}{0} & 25 & 0.75 & 0.32 \\
\hline & 35 & 0.82 & 0.34 \\
\hline & 45 & 0.88 & 0.36 \\
\hline & 55 & 0.91 & 0.40 \\
\hline \multirow{4}{*}{$10^{-6}$} & 25 & 0.73 & 0.29 \\
\hline & 35 & 0.78 & 0.30 \\
\hline & 45 & 0.86 & 0.34 \\
\hline & 55 & 0.89 & 0.38 \\
\hline \multirow{4}{*}{$10^{-5}$} & 25 & 0.67 & 0.24 \\
\hline & 35 & 0.74 & 0.27 \\
\hline & 45 & 0.82 & 0.31 \\
\hline & 55 & 0.87 & 0.34 \\
\hline \multirow{4}{*}{$10^{-4}$} & 25 & 0.64 & 0.17 \\
\hline & 35 & 0.75 & 0.22 \\
\hline & 45 & 0.78 & 0.27 \\
\hline & 55 & 0.83 & 0.29 \\
\hline \multirow{4}{*}{$10^{-3}$} & 25 & 0.39 & 0.08 \\
\hline & 35 & 0.47 & 0.11 \\
\hline & 45 & 0.53 & 0.16 \\
\hline & 55 & 0.55 & 0.19 \\
\hline
\end{tabular}

Table 2. Kinetic parameters for nickel deposition from $5 \mathrm{~g} \mathrm{~L}^{-1} \mathrm{Ni}^{2+}$ without and with different concentrations of $\mathrm{CZ}$, in $25-65^{\circ} \mathrm{C}$ temperature range.

\begin{tabular}{|c|c|c|c|}
\hline CZ Conc. (mol L $\left.{ }^{-1}\right)$ & $t\left({ }^{\circ} \mathrm{C}\right)$ & $1-\alpha$ & $i_{o}\left(\mathrm{~A} \mathrm{~m}^{-2}\right)$ \\
\hline \multirow{5}{*}{0} & 25 & 0.53 & $7.14 \cdot 10^{-4}$ \\
\hline & 35 & 0.57 & $2.72 \cdot 10^{-3}$ \\
\hline & 45 & 0.61 & $1.37 \cdot 10^{-2}$ \\
\hline & 55 & 0.67 & $1.11 \cdot 10^{-1}$ \\
\hline & 65 & 0.74 & $4.60 \cdot 10^{-1}$ \\
\hline \multirow{5}{*}{$10^{-6}$} & 25 & 0.52 & $1.04 \cdot 10^{-4}$ \\
\hline & 35 & 0.56 & $7.42 \cdot 10^{-4}$ \\
\hline & 45 & 0.60 & $5.87 \cdot 10^{-3}$ \\
\hline & 55 & 0.65 & $5.49 \cdot 10^{-2}$ \\
\hline & 65 & 0.69 & $2.15 \cdot 10^{-1}$ \\
\hline \multirow{5}{*}{$10^{-5}$} & 25 & 0.50 & $1.93 \cdot 10^{-5}$ \\
\hline & 35 & 0.54 & $6.90 \cdot 10^{-4}$ \\
\hline & 45 & 0.58 & $5.44 \cdot 10^{-3}$ \\
\hline & 55 & 0.63 & $2.67 \cdot 10^{-2}$ \\
\hline & 65 & 0.67 & $1.92 \cdot 10^{-1}$ \\
\hline \multirow{5}{*}{$10^{-4}$} & 25 & 0.46 & $2.08 \cdot 10^{-6}$ \\
\hline & 35 & 0.51 & $5.52 \cdot 10^{-5}$ \\
\hline & 45 & 0.57 & $1.01 \cdot 10^{-3}$ \\
\hline & 55 & 0.62 & $9.91 \cdot 10^{-3}$ \\
\hline & 65 & 0.65 & $1.10 \cdot 10^{-1}$ \\
\hline \multirow{5}{*}{$10^{-3}$} & 25 & 0.44 & $1.07 \cdot 10^{-8}$ \\
\hline & 35 & 0.49 & $1.84 \cdot 10^{-7}$ \\
\hline & 45 & 0.54 & $5.27 \cdot 10^{-6}$ \\
\hline & 55 & 0.60 & $4.98 \cdot 10^{-5}$ \\
\hline & 65 & 0.63 & $9.20 \cdot 10^{-4}$ \\
\hline
\end{tabular}


The cathodic charge transfer coefficient $1-\alpha$ is strongly influenced by the concentration of $\mathrm{CZ}$ in the electrolyte solution. It can be observed that increasing $\mathrm{CZ}$ concentration in the solution leads to $1-\alpha$ decrease because, according to Bockris et al.'s [37] considerations, the organic molecules are adsorbed at the metal/electrolyte solution interface, which means the reaction plane is shifted towards the bulk of the electrolyte solution. As can be observed from the LVs, this is equivalent with the decrease of the reaction rate, respective of the net density current passing through the electrode.

If temperature rises, the reverse phenomenon is observed; $1-\alpha$ increases since the thermal movement is enhanced and consequently $\mathrm{Cu}^{2+}$ ions can move closer to the metal surface, resulting in the intensification of the deposition process.

For the exchange current density $i_{0}$, appreciable values are obtained in accordance with literature data reported by Farndon et al. [38] and Wan et al. [39]. The addition of $\mathrm{CZ}$ in the electrolyte solution leads to a small diminution of the exchange current density, which demonstrates the slight inhibitory effect of the organic compound on copper electrodeposition. It is worth noting that according with Butler-Volmer relation, the addition of CZ produces an inhibition phenomenon, modifying the kinetic parameters of this process in the direction in which the net current density through the interface is diminished. As expected, the temperature rise involves the increase of exchange current density because the activation energy of the cathodic process decreases.

$\mathrm{CZ}$ addition in the electrolyte solution has similar effect in nickel electrodeposition, but it is far more sensitive. Thus, at $25^{\circ} \mathrm{C}$, the exchange current density decreases more than $10^{4}$ times when $10^{-3} \mathrm{~mol} \mathrm{~L}^{-1} \mathrm{CZ}$ is added in the electrolyte solution. However, the exchange current density values are smaller for nickel than copper deposition and nickel electrodeposition overpotential is higher than for copper. Furthermore, activation energy for nickel deposition is also larger.

In the case of copper electrodeposition, unusually high values are obtained for $1-\alpha$ since the $\mathrm{Cu}^{2+}$ reduction process occurs at high speed, and it is not controlled by the charge transfer process alone. On the other hand, because it is a fast process, the stationary state is not reached even at very low scan rates.

In the ideal case, when the electron transfer is the limiting process, the charge transfer resistance is expressed by Equation (1) [40]:

$$
R_{\mathrm{ct}}=\frac{R T}{(1-\alpha) F i_{0}} \mathrm{e}^{\frac{(1-\alpha) F}{R T} \eta}
$$

where $R$ is gas constant, $T$-thermodynamic temperature, $(1-\alpha)$-cathodic transfer coefficient, $F$-Faraday's number, $\eta$-overpotential.

Knowing the exchange current density values within a limited temperature range, the activation energy for both copper and nickel electrodeposition processes has been calculated based on $\lg \left|i_{0}\right|=f\left(T^{-1}\right)$ dependence [Arrhenius plot given by Equation (2)] [41]:

$$
E_{\mathrm{a}}=-2.303\left(\frac{\partial i_{o}}{\partial T^{-1}}\right)
$$

Analyzing Figure 6, it can be observed that the two electrochemical processes are more sensitive to $\mathrm{CZ}$ addition at low temperatures $\left(25,35^{\circ} \mathrm{C}\right)$. At higher temperatures, the thermal movement increases, diminishing the organic compound inhibitory effect. The calculated values of activation energy are depicted in Table 3. 


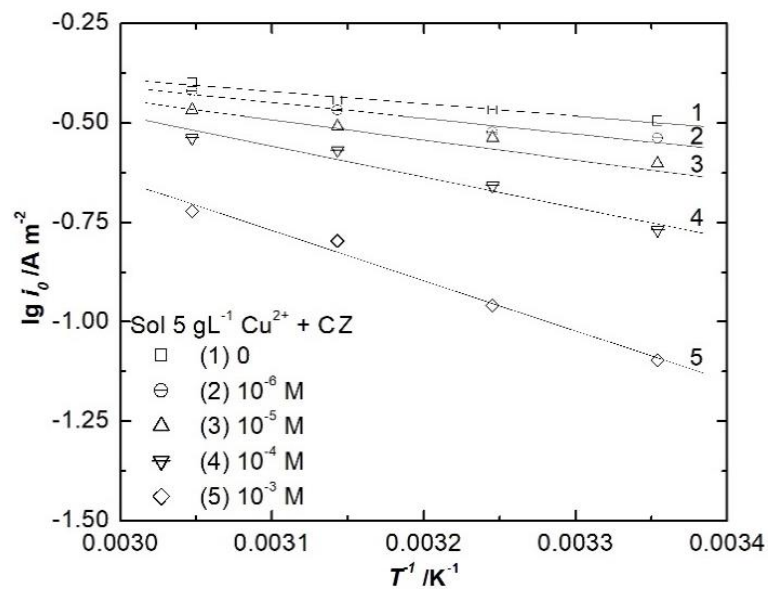

(a)

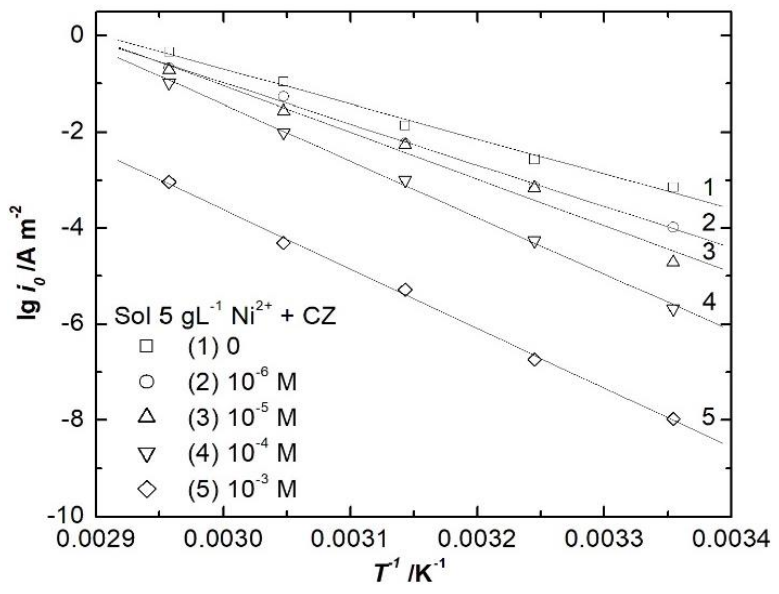

(b)

Figure 6. Arrhenius plots for copper (a) and nickel (b) deposition without and with different concentrations of CZ.

Table 3. Activation energy values for copper and nickel electrodeposition without and with different concentrations of $\mathrm{CZ}$.

\begin{tabular}{ccc}
\hline \multirow{2}{*}{ CZ Conc. $\left(\mathbf{m o l ~ L}^{-1}\right)$} & $\mathbf{C u} / \mathbf{C u}^{2+}$ & $\mathbf{N i} / \mathbf{N i}^{\mathbf{2 +}}$ \\
\cline { 2 - 3 } & \multicolumn{3}{c}{$\boldsymbol{E}_{\boldsymbol{a}} \mathbf{( \mathbf { k J ~ m o l } \mathbf { ~ m o } ^ { - \mathbf { 1 } } )}$} \\
\hline 0 & 5.87 & 139 \\
$10^{-6}$ & 7.59 & 164 \\
$10^{-5}$ & 9.64 & 186 \\
$10^{-4}$ & 14.8 & 225 \\
$10^{-3}$ & 24.2 & 238 \\
\hline
\end{tabular}

Conclusions obtained from the linear voltammetry data are confirmed by the activation energy values. When $\mathrm{CZ}$ is added in the copper and nickel baths, the activation energy increases proportionally with its concentration, therefore $\mathrm{CZ}$ exhibits an inhibitory effect for both electrochemical processes. Generally, it can be stated that copper electrodeposition occurs at a lower overpotential than for nickel, regardless of $\mathrm{CZ}$ addition in the electrolyte solutions.

Information about how the inhibitor acts on the electrodeposition processes has been found based on the adsorption isotherms drawn using the data provided by EIS (Figure 7). Given the chemical structure of CZ, Langmuir isotherm-Equation (3)-is the best approach, according to Koryta et al. [42].

$$
\frac{C_{\mathrm{inh}}}{\theta}=\frac{1}{K_{\mathrm{ads}}}+C_{\mathrm{inh}}
$$

where $C_{\text {inh }}-\mathrm{CZ}$ concentration added in the electrolyte solution $\left(\mathrm{mol} \mathrm{L}^{-1}\right) ; \theta$-coverage degree of the electrode; $K_{\text {ads }}$-adsorption constant.

Representing the linear dependence between $C_{\text {inh }} / \theta$ and $C_{\text {inh }}$ (Figure 7), from abscissa values the adsorption constant $K_{\mathrm{ads}}$ is determined. Further, standard Gibbs energy $\Delta G_{\text {ads }}^{o}$ is calculated using the Equation (4) [43]:

$$
\Delta G_{\mathrm{ads}}^{o}=-R T \ln \left(55.5 K_{\mathrm{ads}}\right)
$$

It is well known that the value of Gibbs free energy gives information about the nature of interactions between the substrate and the adsorbed compound. Amin and Ibrahim [44] suggested that values close to $-20 \mathrm{~kJ} \mathrm{~mol}^{-1}$ show a physical bound between the substrate and the organic compound, while $-40 \mathrm{~kJ} \mathrm{~mol}^{-1}$ indicates a chemical one (chemisorption). Values obtained for copper and nickel electrodeposition are presented in Table 4. 


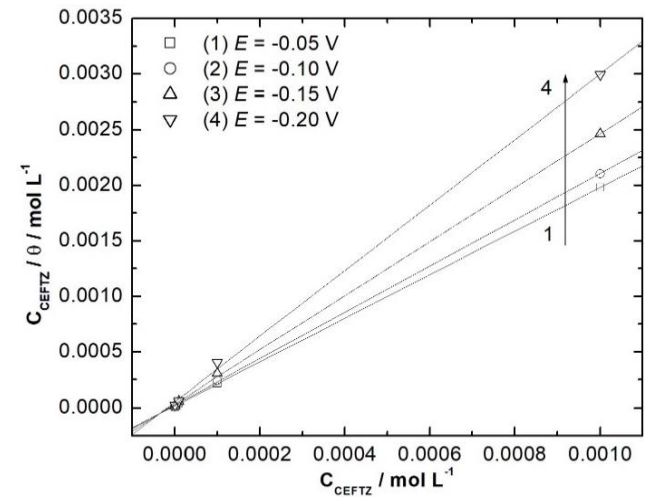

(a)

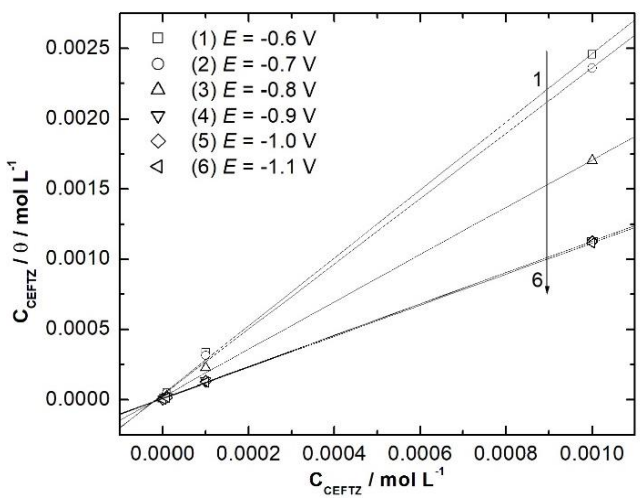

(b)

Figure 7. Langmuir isotherms for copper (a) and nickel electrodeposition (b) at different potential values.

Table 4. Gibbs free energy for nickel and copper deposition at different potentials.

\begin{tabular}{ccc}
\hline Process & $\mathbf{E}(\mathbf{V})$ & $\Delta G_{\mathbf{a d s}}^{\mathbf{o}} \mathbf{( \mathbf { k J ~ m o l }} \mathbf{~ m}^{\mathbf{- 1}} \mathbf{)}$ \\
\hline \multirow{3}{*}{ Nickel electrodeposition } & -0.6 & -35.0 \\
& -0.7 & -35.3 \\
& -0.8 & -36.6 \\
Copper electrodeposition & -0.9 & -38.0 \\
& -1.0 & -38.9 \\
& -1.1 & -39.7 \\
\hline
\end{tabular}

Both in nickel and copper cases, $\Delta G_{\text {ads }}^{o}$ values are close to $-40 \mathrm{~kJ} \mathrm{~mol}^{-1}$ which indicates that during the electrodeposition, $\mathrm{CZ}$ is chemically adsorbed onto the metal surface.

\subsection{Morphological Characterization}

To highlight CZ influence on the morphology of the metallic layers obtained by electrodeposition, copper and nickel industrial bath were used. In those baths, CZ was added, and the morphologies of the layers deposited without and with $\mathrm{CZ}$ were compared. The layers have been deposited using the following parameters (Table 5):

Table 5. Electrodeposition parameters.

\begin{tabular}{|c|c|c|}
\hline \multirow{5}{*}{ Copper deposition } & Substrate & $\mathrm{Cu}$ \\
\hline & Electrodeposition bath & $\begin{array}{l}250 \mathrm{~g} \mathrm{~L}^{-1} \mathrm{CuSO}_{4} \cdot 5 \mathrm{H}_{2} \mathrm{O} \\
0.5 \mathrm{~mol} \mathrm{~L}-1 \mathrm{H}_{2} \mathrm{SO}_{4} \\
\text { without/with } 10^{-4} \mathrm{~mol} \mathrm{~L}^{-1} \mathrm{CZ}\end{array}$ \\
\hline & Current density & $100 \mathrm{~A} \mathrm{~m}^{-2}$ \\
\hline & Time & $15 \mathrm{~min}$ \\
\hline & Temperature & $25^{\circ} \mathrm{C}$ \\
\hline \multirow{5}{*}{ Nickel deposition } & Substrate & $\mathrm{Cu}$ \\
\hline & Electrodeposition bath & $\begin{array}{l}300 \mathrm{~g} \mathrm{~L}^{-1} \mathrm{NiSO}_{4} \cdot 7 \mathrm{H}_{2} \mathrm{O} \\
45 \mathrm{~g} \mathrm{~L}^{-1} \mathrm{NiCl}_{2} \cdot 6 \mathrm{H}_{2} \mathrm{O} \\
30 \mathrm{~g} \mathrm{~L}^{-1} \mathrm{H}_{3} \mathrm{BO}_{3} \\
\text { without/with } 10^{-4} \mathrm{~mol} \mathrm{~L}^{-1} \mathrm{CZ}\end{array}$ \\
\hline & Current density & $200 \mathrm{~A} \mathrm{~m}^{-2}$ \\
\hline & Time & $10 \mathrm{~min}$ \\
\hline & Temperature & $25^{\circ} \mathrm{C}$ \\
\hline
\end{tabular}


Figure 8 illustrates the images obtained by optical microscopy for copper layers, and for nickel respectively. For both metals, there are presented comparatively the deposits obtained without and with $\mathrm{CZ}$ addition.

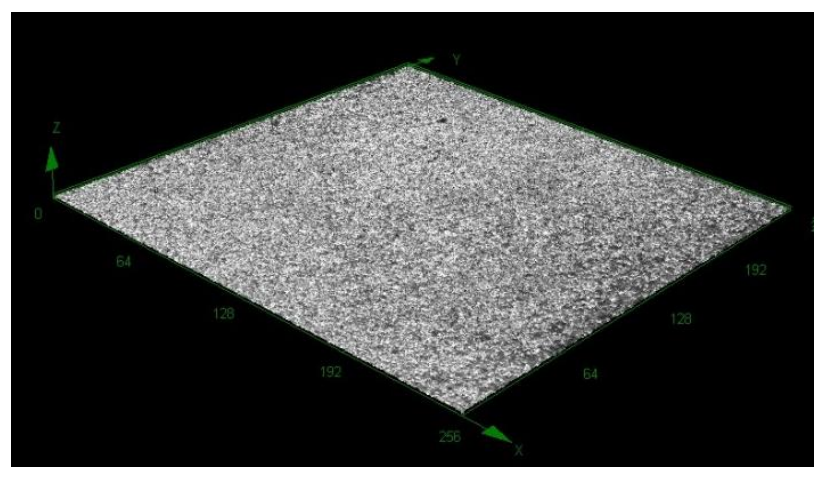

(a)

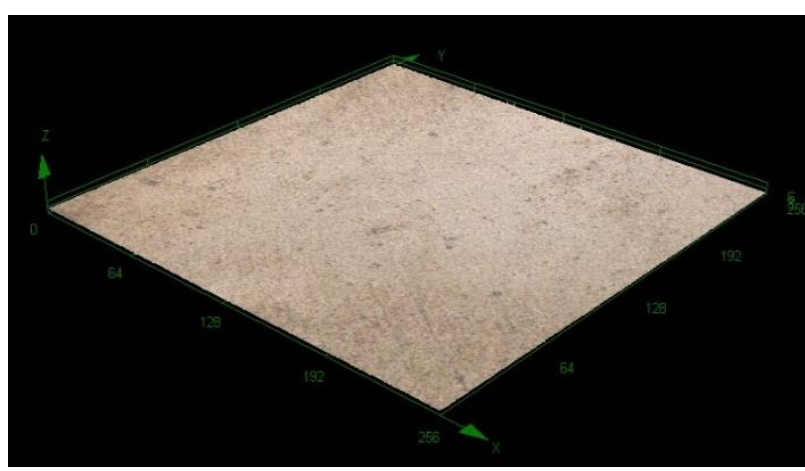

(c)

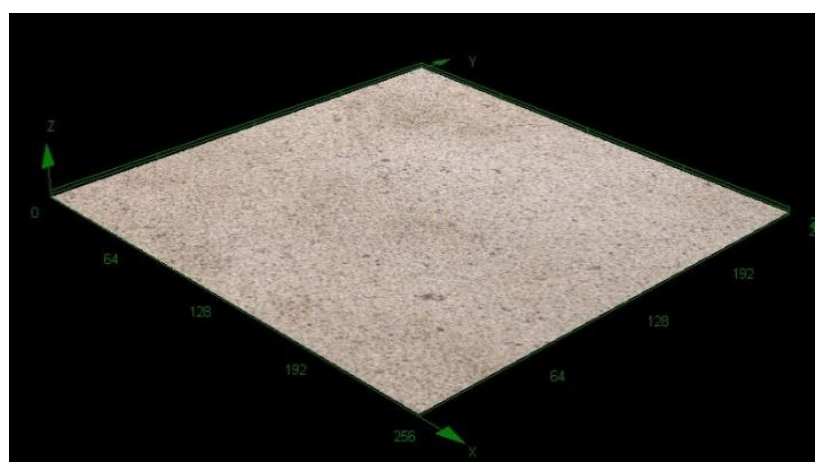

(b)

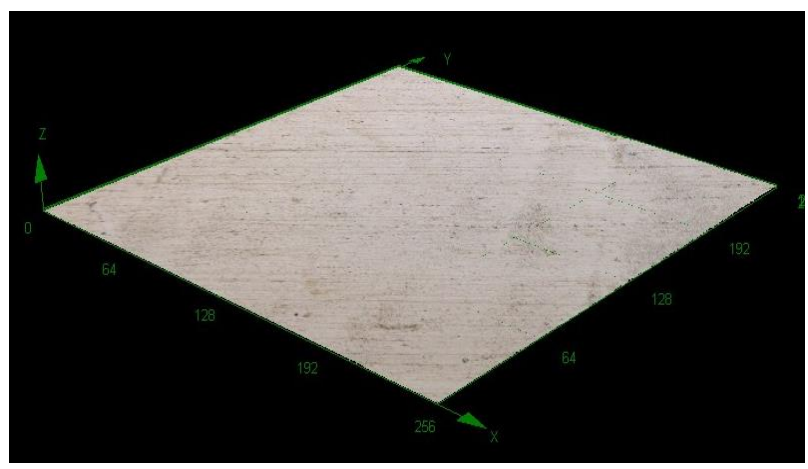

(d)

Figure 8. Images for copper $(\mathbf{a}, \mathbf{b})$ and nickel electrodeposition $(\mathbf{c}, \mathbf{d})$ without/with $10^{-4} \mathrm{~mol} \mathrm{~L}^{-1} \mathrm{CZ}$, magnification: $50 \times$.

It can be seen that in the absence of $\mathrm{CZ}$ a rough structure is obtained, while when a small amount $\left(10^{-4} \mathrm{~mol} \mathrm{~L}^{-1}\right)$ of $\mathrm{CZ}$ is added in the electrodeposition bath, the layers have a bright aspect in both copper and nickel cases. For all samples, 5 different areas were investigated on each sample and the average values for the mean roughness parameters $\left(R_{\mathrm{a}}\right)$ were: for copper deposition (without $\mathrm{CZ}-10.3 \mu \mathrm{m}$ and with $\mathrm{CZ}-1.84 \mu \mathrm{m}$ ) and for nickel deposition (without CZ-1.02 $\mu \mathrm{m}$ and with CZ-0.128 $\mu \mathrm{m}$ ). If a higher concentration of $\mathrm{CZ}$ is added, the layers are qualitative inadequate, having a matte look.

\section{Conclusions}

In this paper, the possibility of using $\mathrm{CZ}$, the active substance from Ceftamil ${ }^{\circledR}$ pharmaceutical drug as an additive in copper and nickel acid baths was studied.

Cyclic voltammetry was conducted in order to emphasize the electrochemical behavior and stability of $\mathrm{CZ}$ in acid media, similar to the galvanic baths used at commercial level. It was found that in strong acid media $\left(\mathrm{H}_{2} \mathrm{SO}_{4}\right), \mathrm{CZ}$ does not undergo electrochemical transformations, while in weak acid media $\left(\mathrm{H}_{3} \mathrm{BO}_{3}\right)$, at advanced anodic polarization, it oxidizes to different compounds. However, $\mathrm{CZ}$ can be used in both baths since the polarization is not pronounced enough during the metal deposition to oxidize the compound.

LV studies proved that CZ acts as an inhibitor on the studied processes, the copper and nickel characteristic overpotentials being shifted towards more negative values, proportional with the amount of $\mathrm{CZ}$ added in the electrolyte solution. Based on the LVs, from Tafel plots, kinetic parameters (charge transfer coefficient 1- $\alpha$ and the exchange current density $i_{0}$ ) for copper and nickel deposition have been calculated. In nickel case, the increase of $1-\alpha$ and the advanced decrease of $i_{0}\left(10^{4}\right.$ times) are observed with the increase of CZ 
concentration in the electrolyte solution, meaning the reaction plane is shifted toward the solution bulk due to the partially block of the electrode surface with CZ large molecules, inhibiting thus the deposition process. In copper case, a similar but not as advanced effect as for nickel is noticed. With the increase of temperature from 25 to $65^{\circ} \mathrm{C}$, the reverse phenomenon is observed, the processes being accelerated as a result of the thermal movement intensification.

As well, the activation energy values, obtained from Arrhenius plots, confirm the inhibitory effect of $C Z, E_{\mathrm{a}}$ increasing with the increase of $\mathrm{CZ}$ amount added in the electrolyte solution.

Forwards, from Langmuir isotherms, Gibbs free energy was approximated. The values are close to $-40 \mathrm{~kJ} \mathrm{~mol}^{-1}$, suggesting a chemical adsorption of CZ onto the metallic electrode surface.

The morphology of the copper and nickel deposited layers showed CZ has a levelling effect when it is used as additive in small concentration; the proper amount to be used is about $10^{-4} \mathrm{~mol} \mathrm{~L}^{-1}$, at higher concentrations, the layers are qualitatively inadequate.

Supplementary Materials: The following are available online at https: / www.mdpi.com/article/ 10.3390/ijerph18189476/s1, Figure S1: Tafel plots for copper electrodeposition without and with different concentrations of $\mathrm{CZ}$ at $25^{\circ} \mathrm{C}$ (a) and with $10^{-3} \mathrm{~mol} \mathrm{~L}{ }^{-1} \mathrm{CZ}$ at different temperatures (b), $2 \mathrm{mV} \mathrm{s}^{-1}$ scan rate, Figure S2: Tafel plots for nickel electrodeposition without and with different concentrations of $\mathrm{CZ}$ at $25^{\circ} \mathrm{C}$ (a) and with $10^{-3} \mathrm{~mol} \mathrm{~L}^{-1} \mathrm{CZ}$ at different temperatures (b), $2 \mathrm{mV} \mathrm{s}^{-1}$ scan rate, Figure S3: Nyquist (a) and Bode plots (b) recorded on nickel electrode in $5 \mathrm{~g} \mathrm{~L}^{-1} \mathrm{Ni}^{2+}$ different $C Z$ concentrations at $E=-0.80 \mathrm{~V}$, Figure S4: Nyquist (a) and Bode plots (b) recorded on nickel electrode in $5 \mathrm{~g} \mathrm{~L}^{-1} \mathrm{Ni}^{2+}$ different $\mathrm{CZ}$ concentrations at $\mathrm{E}=-0.80 \mathrm{~V}$, Figure S5: Equivalent electrical circuit for modelling nickel (a) and copper (b) electrodeposition, Table S1: Calculated data of the circuit elements and experimental errors (between brackets, \%) for nickel electrodeposition, Table S2: Calculated data of the circuit elements and experimental errors (between brackets, \%) for copper electrodeposition.

Author Contributions: Conceptualization, N.V.; methodology, D.-A.D., M.L.D.; software, D.-A.D., M.L.D.; validation, M.L.D., N.V.; formal analysis, D.-A.D., M.L.D.; investigation, D.-A.D., M.L.D.; resources, M.L.D., N.V.; data curation, N.V.; writing—original draft preparation, D.-A.D.; writingreview and editing, D.-A.D., M.L.D., V.N; visualization, D.-A.D., M.L.D.; supervision, N.V.; project administration, N.V.; funding acquisition, M.L.D. All authors have read and agreed to the published version of the manuscript.

Funding: This research received no external funding.

Institutional Review Board Statement: Not applicable.

Informed Consent Statement: Not applicable.

Data Availability Statement: Data sharing is not applicable to this article.

Acknowledgments: This work was supported by University Politehnica Timisoara in the frame of PhD studies.

Conflicts of Interest: The authors declare no conflict of interest.

\section{References}

1. Akici, A.; Aydin, V.; Kiroglu, A. Assessment of the association between drug disposal practices and drug use and storage behaviors. Saudi Pharm. J. 2018, 26, 7-13. [CrossRef]

2. Kozak, M.A.; Melton, J.R.; Gernant, S.A.; Snyder, M.E. A needs assessment of unused and expired medication disposal practices: A study from the Medication Safety Research Network of Indiana. Res. Soc. Adm. Pharm. 2016, 12, 336-340. [CrossRef]

3. Nour, I.E.M.; Elnour, A.A.; Salih, T.J.M.; Al Mulla, W.M.; Bhagavathula, A.S. Management of Post-Consumer Pharmaceutical Waste: An Overview. SOJ Pharm. Pharm. Sci. 2017, 4, 1-5. [CrossRef]

4. Lu, M.C.; Chen, Y.Y.; Chiou, M.-R.; Chen, M.Y.; Fan, H.-J. Occurrence and treatment efficiency of pharmaceuticals in landfill leachates. Waste Manag. 2016, 55, 257-264. [CrossRef]

5. Li, D.; Guo, X.; Song, H.; Sun, T.; Wan, J. Preparation of $\mathrm{RuO}_{2}-\mathrm{TiO}_{2} /$ Nano-graphite composite anode for electrochemical degradation of ceftriaxone sodium. J. Hazard. Mater. 2018, 351, 250-259. [CrossRef] 
6. Persson, M.; Sabelstrom, E.; Gunnarsson, B. Handling of unused prescription drugs—Knowledge, behaviour and attitude among Swedish people. Environ. Int. 2009, 35, 771-774. [CrossRef] [PubMed]

7. Tong, A.Y.C.; Peake, B.M.; Braund, R. Disposal practices for unused medications around the world. Environ. Int. 2011, 37, 292-298. [CrossRef] [PubMed]

8. Tsakona, M.; Anagnostopoulou, E.; Gidarakos, E. Hospital waste management and toxicity evaluation: A case study. Waste Manag. 2007, 27, 912-920. [CrossRef]

9. Hossain, M.S.; Santhanam, A.; Norulaini, N.A.N.; Mohd Omar, A.K. Clinical solid waste management practices and its impact on human health and environment-A review. Waste Manag. 2011, 31, 754-766. [CrossRef]

10. Kadam, A.; Patil, S.; Patil, S.; Tumkur, A. Pharmaceutical Waste Management an Overview. IJOPP 2016, 9, 2-8. [CrossRef]

11. Ruhoy, I.S.; Daughton, C.G. Beyond the medicine cabinet: An analysis of where and why medications accumulate. Environ. Int. 2008, 34, 1157-1169. [CrossRef] [PubMed]

12. Glassmeyer, S.T.; Hinchey, E.K.; Boehme, S.E.; Daughton, C.G.; Ruhoy, I.S.; Conerly, O.; Daniels, R.L.; Lauer, L.; McCarthy, M.; Nettesheim, T.G.; et al. Disposal practices for unwanted residential medications in the United States. Environ. Int. 2009, 35, 566-572. [CrossRef] [PubMed]

13. Komilis, D.; Fouki, A.; Papadopoulos, D. Hazardous medical waste generation rates of different categories of health-care facilities. Waste Manag. 2012, 32, 1434-1441. [CrossRef]

14. Mezzelani, M.; Gorbi, S.; Regoli, F. Pharmaceuticals in the aquatic environments: Evidence of emerged threat and future challenges for marine organisms. Mar. Environ. Res. 2018, 140, 41-60. [CrossRef]

15. Gonzalez, O.I.P.; Zavala, M.A.L.; Ruelas, H.C. Pharmaceutical Market, Consumption Trends and Disease Incidence Are Not Driving the Pharmaceurical Research on Water and Wastewater. Int. J. Environ. Res. Public Health 2021, 18, 2532. [CrossRef]

16. Pepper, I.L.; Brooks, J.P.; Gerba, C.P. Antibiotic Resistant Bacteria in Municipal Wastes: Is There Reason for Concern? Environ. Sci. Technol. 2018, 52, 3949-3959. [CrossRef] [PubMed]

17. Liu, W.; Iordan, C.M.; Cherubini, F.; Hu, X.; Fu, D. Environmental impacts assessment of wastewater treatment and sludge disposal systems under two sewage discharge standards: A case study in Kunshan, China. J. Clean Prod. 2021, 287, 125046. [CrossRef]

18. Yu, X.; Hu, X.; Li, S.; Zhang, M.; Wang, J. Attitudes and Practice Regarding Disposal for Unwanted Medications among Young Adults and Elderly People in China from an Ecopharmacovigilance Perspective. Int. J. Environ. Res. Public Health 2019, 16, 1463. [CrossRef]

19. Jung, F.; Thurn, M.; Krollik, K.; Gao, G.F.; Hering, I.; Eilebrecht, E.; Emara, Y.; Weiler, M.; Günday-Türeli, N.; Türeli, E.; et al. Predicting the environmental emissions arising from conventional and nanotechnology-related pharmaceutical drug products. Environ. Res. 2021, 192, 110219. [CrossRef] [PubMed]

20. Duca, D.A.; Dan, M.L.; Vaszilcsin, N. Reuse of expired cefort drug in copper electrodeposition from acid bath. Ann. Univ. Oradea-Environ. Prot. 2016, 27, 229-236.

21. Duca, D.A.; Dan, M.L.; Vaszilcsin, N. Reuse of Expired Cefort Drug in Nickel Electrodeposition from Watts Bath. Chem. J. Mold. 2017, 12, 87-94. [CrossRef]

22. Duca, D.A.; Vaszilcsin, N.; Dan, M.L. Recycling of expired midazolam as levelling agent in a Watts electroplating bath. SGEM Conf. Proc. 2016, 4, 105-112.

23. Hou, H.; Dai, Z.; Liu, X.; Yao, Y.; Liao, Q.; Yu, C.; Li, D. Reutilization of the expired tetracycline for lithium ion battery anode. Sci. Total Environ. 2018, 630, 495-501. [CrossRef] [PubMed]

24. Gece, G. Drugs: A review of promising novel corrosion inhibitors. Corros. Sci. 2011, 53, 3873-3898. [CrossRef]

25. Vaszilcsin, N.; Ordodi, V.; Borza, A. Corrosion Inhibitors from Expired Drugs. Int. J. Pharm. 2012, 431, 241-244. [CrossRef] [PubMed]

26. Singh, A.K.; Shukla, S.K.; Quraishi, M.A. Corrosion Behaviour of Mild Steel in Sulphuric Acid Solution in Presence of Ceftazidime. Int. J. Electrochem. Sci. 2011, 6, 5802-5814.

27. Pletcher, D.; Walsh, F.C. Industrial Electrochemistry, 2nd ed.; Springer Netherlands: Heidelberg, Germany, 1993 ; pp. 385-450.

28. Isserlis, G. The electrolytic finishing of metals. In Industrial Electrochemical Processes; Kuhn, A.T., Ed.; Elsevier Publishing Company: Amsterdam, The Netherlands; London, UK; New York, NY, USA, 1971; pp. 327-383.

29. Lyons, E.H., Jr. Fundamental principles. In Modern Electroplating; Lowenheim, F.A., Ed.; Wiley-Interscience Publication: New York, NY, USA; London, UK; Sydney, Australia; Toronto, ON, Canada, 1974; pp. 1-45.

30. Kardos, O.; Gardner, D. Applications of mass transport theory: Electrodeposition on small-scale profiles. In Advances in Electrochemistry and Electrochemical Engineering; Tobias, C.W., Ed.; Wiley Interscience: New York, NY, USA, $1962 ;$ pp. 145-233.

31. Oniciu, L.; Muresan, L. Some fundamental aspects of levelling and brightening in metal electrodeposition. J. Appl. Electrochem. 1991, 21, 565-574. [CrossRef]

32. Paunovic, M.; Schlesinger, M.; Snyder, D.D. Fundamental considerations. In Modern Electroplating, 5th ed.; Schlesinger, M., Paunovic, M., Eds.; Wiley and Sons: Hoboken, NJ, USA, 2010; pp. 1-32.

33. Schweitzer, P.A. Fundamentals of Corrosion: Mechanisms, Causes, and Preventative Methods; CRC Press-Taylor \&Francis Group: Boca Raton, FL, USA; London, UK, 2009.

34. Badarulzaman, N.A.; Mohamad, A.A.; Puwadaria, S.; Ahmad, Z.A. The evaluation of nickel deposit obtained via Watts electrolyte at ambient temperature. J. Coat. Technol. Res. 2010, 7, 815-820. [CrossRef] 
35. Pasquale, M.A.; Gassa, L.M.; Arvia, A.J. Copper electrodeposition from an acidic plating bath containing accelerating and inhibiting organic additives. Electrochim. Acta 2008, 53, 5891-5904. [CrossRef]

36. Holze, R. Experimental Electrochemistry: A Laboratory Textbook; Wiley-VCH Verlag: Weinheim, Germany, 2009.

37. Bockris, J.O.; Reddy, A.K.N.; Gamboa-Aldeco, M.E. Modern Electrochemistry, 2nd ed.; Kluwer Academic Publishers: New York, NY, USA, 2000; pp. 1479-1487.

38. Farndon, E.E.; Walsh, F.C.; Cambell, S.A. Effect of thiourea, benzotriazole and 4,5-dithiaoctane-1,8 disulphonic acid on the kinetics of copper deposition from dilute acid sulphate solutions. J. Appl. Electrochem. 1994, 25, 574-583. [CrossRef]

39. Wan, C.C.; Cheh, H.Y.; Linford, H.B. A study of electrochemical kinetics of copper deposition under pulsed current conditions. J. Appl. Electrochem. 1979, 9, 29-35. [CrossRef]

40. Kellenberger, A.; Vaszilcsin, N. Electrochimia Starii Solide; Editura Politehnica: Timisoara, Romania, 2013 ; pp. 19-34.

41. Palomar-Pardavé, M.; Aldana-González, J.; Botello, L.E.; Arce-Estrada, E.M.; Ramírez-Silva, M.T.; Mostany, J.; Romero-Romo, M. Influence of temperature on the thermodynamics and kinetics of cobalt electrochemical nucleation and growth. Electrochim. Acta 2017, 241, 162-169. [CrossRef]

42. Koryta, J.; Dvorak, J.; Kavan, L. Principles of Electrochemistry, 2nd ed.; John Wiley and Sons: West Sussex, UK, 1993 ; pp. $246-409$.

43. Kiani, M.A.; Mousavi, M.F.; Ghasemi, S.; Shamsipur, M.; Kazemi, S.H. Inhibitory effect of some amino acids on corrosion of $\mathrm{Pb}-\mathrm{Ca}-\mathrm{Sn}$ alloy in sulfuric acid solution. Corros. Sci. 2008, 50, 1035-1045. [CrossRef]

44. Amin, M.A.; Ibrahim, M.M. Corrosion and corrosion control of mild steel in concentrated $\mathrm{H}_{2} \mathrm{SO}_{4}$ solutions by a newly synthesized glycine derivative. Corros. Sci. 2011, 53, 873-885. [CrossRef] 